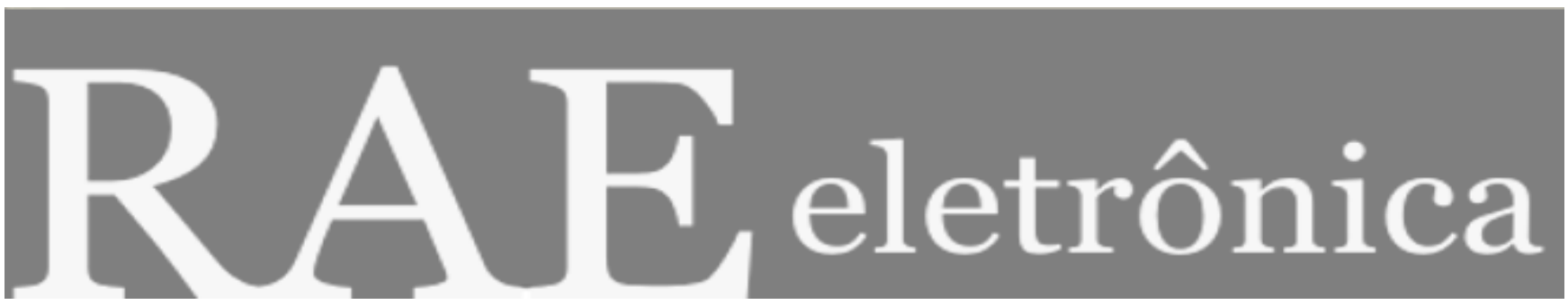

\title{
A RESPEITO DE ÉTICA E FINANÇAS
}

Por:

\section{Luís Fernando Moreira}

RAE-eletrônica, Volume 1, Número 2, jul-dez/2002.

http://www.rae.com.br/eletronica/index.cfm?FuseAction=Artigo\&ID=390\&Secao=FINANÇAS2\&Vol ume $=1 \&$ Numero $=2 \&$ Ano $=2002$

(C)Copyright, 2002, RAE-eletrônica. Todos os direitos, inclusive de tradução, são reservados. É permitido citar parte de artigos sem autorização prévia desde que seja identificada a fonte. A reprodução total de artigos é proibida. Os artigos só devem ser usados para uso pessoal e nãocomercial. Em caso de dúvidas, consulte a redação: redacao@,rae.com.br.

A RAE-eletrônica é a revista on-line da FGV-EAESP, totalmente aberta e criada com o objetivo de agilizar a veiculação de trabalhos inéditos. Lançada em janeiro de 2002, com perfil acadêmico, é dedicada a professores, pesquisadores e estudantes. Para mais informações consulte o site www.rae.com.br/eletronica.

RAE-eletrônica

ISSN 1676-5648

(C2002 Editora: Fundação Getulio Vargas - Escola de Administração de Empresas de São Paulo.

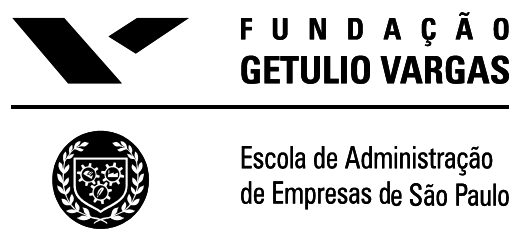




\title{
A RESPEITO DE ÉTICA E FINANÇAS
}

\section{Luís Fernando Moreira}

Professor da UNIOESTE e UNIPAR. Mestre em Administração [finanças] EA-PPGA-UFRGS.

E-mail: moreiralf@wopm.com.br

Endereço: Av.: Brasil, 9583 Ap. 14 Bl. 01 - Coqueiral - Cascavel, PR 85807-030.

Interesses de Pesquisa: Finanças corporativas, Mercado de capitais.

\section{RESUMO}

Ética é tema bastante atual e vários artigos o tem contemplado. Por outro lado, a ética na área de finanças não tem recebido grande atenção no Brasil. O artigo leva o debate também para esta esfera e sugere caminhos para pesquisas futuras. Este artigo apresenta as principais abordagens da ética e suas implicações para a área de finanças. Dentre os assuntos discutidos estão problemas de agência, ética da virtude em finanças, o sistema legal e suas implicações sobre a eficiência de mercado, fundos de investimento ético e ética nos negócios e a maximização da riqueza dos acionistas. O autor propõe que o comportamento ético de um agente deve ser aquilatado com base nos resultados práticos de suas ações e que as ações de uma empresa devem estar centradas em sua clientela.

\begin{abstract}
Ethics is a current topic and a lot of papers have considered it. On the other hand, ethics in finance have not deserved so much attention in Brazil. The paper brings the debate to this sphere and suggests courses to future researches. This paper provides an examination of the main currents of ethics and its implication to the finance field. Among the issues discussed are agency problems, virtue ethics in finance, the legal system of justice and its implication to the market efficiency, ethical investment funds, and business ethics and shareholders wealth maximisation. The author proposes that the ethical behaviour of an agent should be judged only by the practical results of his actions and that the ethics of a firm should be centred on its clientele.
\end{abstract}

\section{PALAVRAS-CHAVE}

Finanças, ética nos negócios, ética e finanças, ética, filosofia política.

\section{KEY WORDS}

Finance, business ethics, ethics and finance, ethics, political science. 


\section{INTRODUÇÃO}

Ao tratar de temas complexos como é o caso da ética, freqüentemente me encontro na desconfortável situação de nada dizer ou optar por uma exposição imperfeita. A simplificação e a síntese nos auxiliam sobremaneira a compreender assuntos complexos, entretanto a brevidade pode nos levar a compreender imperfeitamente, dada a série de omissões que lhe são inerentes. Porém, a vida é curta e o conhecimento, ilimitado. Sintetizar é um mal necessário, pelo que, o que tenho a oferecer é, obviamente, uma visão parcial, geral e, sob muitos aspectos, pessoal. A obrigação de quem sintetiza é procurar fazê-lo da melhor maneira possível, mesmo sabendo que o resultado é essencialmente insatisfatório. Procurei, por isso, ao mesmo tempo, concisão e clareza, porém, propositadamente, não a persuasão. Cabe ao leitor a liberdade de decidir a respeito da qualidade do que lhe apresento.

Afinal, como podemos acomodar ética e finanças; e em termos mais genéricos, ética e negócios? O que é ser ético do ponto de vista dos administradores empresariais, dos acionistas, dos empregados, dos consumidores e dos legisladores? Será crível que estes indivíduos em posições tão distintas compartilhem da mesma opinião sobre o assunto? Em caso afirmativo, deve existir um conjunto de valores absolutos e imutáveis; caso contrário temos um relativismo absoluto, um relativismo parcial, ou o que? Podem diferir de opinião os indivíduos em questão e ainda assim estarem todos certos? Quais as implicações da maximização da riqueza dos acionistas do ponto de vista ético? Ética nos negócios tem valor? Em caso afirmativo como quantificá-la? A quantidade de perguntas e respostas é provavelmente infinita. Este artigo não tem a pretensão de responder perguntas, seu objetivo precípuo é aguçar e provocar o leitor, leva-lo a utilizar a razão, enfim, pensar sobre o assunto.

Na seção 2, apresento algumas abordagens sobre o tema, o objetivo é criar o pano de fundo adequado para desenvolvimento do artigo. Na seção 3, trato de ética nos negócios em geral. Na seção 4, abordado diversos aspectos de finanças que guardam alguma questão de cunho ético. Na seção 5, faço uma breve análise crítica dos itens abordados na seção anterior. As conclusões apresento na seção seguinte, encerrando o artigo.

\section{ÉTICA EM GERAL}

Sempre que penso com alguma profundidade a respeito de ética, assunto para mim bastante espinhoso, acabo invariavelmente perplexo e sempre que sou chamado a expressar verbalmente minhas opiniões a respeito de alguma questão que envolva este tipo de abordagem, acabo quase sempre no limbo do que chamarei relativismo absoluto. Claro que quando alguém me pergunta "o que você faria se..." sempre saio com uma resposta; daí a dizer que seria mesmo a melhor possibilidade não me arrisco; entretanto lembro a observação de Jon Elster “... as vezes o que importa é alcançar alguma decisão, quase qualquer decisão, mais do que a mítica melhor decisão” (Elster, 1993, p. 111). Qual de nós já não agiu de modo maquiavélico pelo menos uma vez? Qual de nós já não foi vítima de tal comportamento por parte de um terceiro? E qual de nós já não foi vítima do próprio romantismo, tendo agido de modo tão inocente que tornou-se um alvo perfeito para uma atitude pouco ética?

Eu diria que ninguém é capaz de agir mal todo o tempo e com todos. Existe a meu ver uma dimensão afetiva no ser humano que deve ser preenchida e penso que alguém que fosse todo o tempo bom ou todo o tempo ruim seria visto como uma avis rara e internado em um manicômio. É em função de sermos capazes de agir bem ou mal que surgem os problemas éticos e a razão pela qual tais problemas 
são tão difíceis, é que não é possível uma definição de bem e mal absolutos, as dimensões desses termos e a fronteira entre eles são relativas e sua definição é antes de tudo uma questão de posição.

A idéia da inexistência de um conjunto de valores absolutos e imutáveis é recente e surge com o fenômeno da emergência da modernidade - big ditch theory (Santos, 1990). Até o final da idade média a ética era, basicamente, aristotélica, ou seja, acreditava-se em um absolutismo ético. Aristóteles acreditava que as pessoas buscavam o que era bom (felicidade). Para evitar o relativismo implícito em seu ponto de vista ele dividiu os desejos em naturais e adquiridos. Os desejos naturais eram sempre bons, pois eram considerados inerentes aos Homens e por isso mesmo não poderia haver erro em desejá-los. O problema da construção genial de Aristóteles surge com os desejos adquiridos, pois aqui é pouco clara a diferenciação entre certo e errado e tudo passa a depender do "bom julgamento moral do agente". Aristóteles aponta três virtudes que devem ser cultivadas para alcançá-lo: temperança, coragem e justiça. Possuindo tais virtudes o agente teria um comprometimento no sentido de que o que lhe conviesse fosse igualmente bom para os outros (Compton's Interactive Encyclopedia, 1996).

O capitulo XV de O Príncipe (Maquiavel, 1996) parece bastante condizente com a realidade atual, embora seu texto tenha sido escrito em 1513. Para mim é como se Aristóteles tratasse de ética normativa e Maquiavel de ética descritiva; em outras palavras desejaríamos realmente ser o Homem de Aristóteles, mas o máximo que conseguimos é um equilíbrio precário que nos coloca mais próximos do Homem de Maquiavel. Santos (1997) chama a atenção para a contribuição de Maquiavel à um raciocínio moral pragmático, referindo-se ao mesmo capitulo de O Príncipe. Isaiah Berlin observa que "Maquiavel limita-se a observar que as duas moralidades [cristã e pagã] são incompatíveis, e não reconhece nenhum critério superior que nos permita decidir qual é a vida correta a ser vivida pelos homens" (Berlin, 1991, p. 19). As observações de Maquiavel podem ser rotuladas por muitos como sendo 'frias', 'pessimistas' ou mesmo 'cruéis', mas é inegável que, ao admitir a coexistência de vícios e virtudes em cada um de nós e ao apontar a impossibilidade de eliminar por completo tal dicotomia, descreveu melhor a realidade e representou uma evolução em relação ao pensar aristotélico.

Ernest Gellner (1995) ao abordar as diferenças de opinião entre relativistas, fundamentalistas e aos que chama "puritanos do iluminismo" aponta o papel fundamental de tais diferenças em uma sociedade liberal por facilitar uma mistura de convicção e tolerância. Santos (1991) diz que "...ao ampliarmos o escopo ou a dimensão da Ética, a preponderância do social mais e mais se evidencia. Evidenciam-se, também, as feições seletivas ou até elitistas da Ética individual." (Santos, 1991, p. 3). Este autor explica que toda abordagem da ética deve ser via uma dialética histórica que considere o caráter mutável e evolutivo dos valores. Isaiah Berlin (1991) aponta para a impossibilidade de um bloco de valores morais fixos e válidos para todos. A diversidade conduz à criação de valores próprios em cada sociedade. Por outro lado, embora com valores distintos, é possível que um povo compreenda e respeite os valores dos outros. Isto pode ocorrer porque o que faz de nós, homo sapiens, aquilo que somos, estabelece uma ponte entre nós, é algo comum a todos de nossa espécie, a razão. Nossos valores são nossos valores, os valores de outras culturas podem ser radicalmente diferentes dos nossos, porém não podemos alegar que não os compreendemos em absoluto. A razão permite a intercomunicação dos seres humanos no tempo e no espaço. O que há de fato, é um pluralismo de fins (todos válidos) que podem ser buscados pelo Homem. Berlin afirma que essa ótica tem sido chamada "relativismo cultural ou moral", mas este autor diz não ser este o caso, e chama essa ótica de pluralismo.

A ética é criada, construída socialmente no coletivo. O problema ético surge em função da dificuldade em definir-se bem e mal e da vida em grupo. Imagino um exemplar do homo sapiens com todo o planeta a sua disposição, o único de sua espécie a habitá-lo, e imediatamente o aspecto ético torna-se simples e até irrelevante: "tudo que este indivíduo considerar bom para si, será bom e, 
automaticamente, ético". A existência de outros membros da mesma espécie compartilhando o mesmo espaço é que explica e legitima a existência de uma ética a ser seguida. Esta ética pode ser aplicável a toda a sociedade ou apenas a um determinado grupo dentro de dada sociedade. A ética aqui descrita representa antes de tudo uma restrição a liberdade individual; o paradoxo é que ao mesmo tempo, esta mesma ética, garante um nível mínimo de liberdade (BERLIN, 1981). A ética esta expressa nas normas sociais em geral; as leis neste contexto determinam o padrão ético mínimo esperado (Santos,1997). Entretanto não há garantias de que certas leis não sejam discriminatórias, injustas ou sirvam aos interesses de uns poucos membros da sociedade. Por outro lado, em uma sociedade democrática de fato e de direito, seria de esperar que as leis representassem a média daquilo que a sociedade considera mínimo para uma convivência pacífica.

Mas a ética vai muito além da norma jurídica. Entretanto, se o comportamento ético além do que a lei estabelece não é obrigatório e representa, em última análise, uma restrição a liberdade, como explicar que determinados indivíduos ou grupos de indivíduos estabeleçam padrões acima daqueles que a lei determina? Para elucidar este ponto creio ser útil aproveitar o raciocínio de Elster em seu ensaio seminal Egonomics: the economics of personal conflict em que estabelece duas condições para que uma norma seja social. Em primeiro lugar, deve ser compartilhada com outras pessoas e em segundo lugar, deve ser reforçada em parte pelas sanções de outras pessoas. "O principal reforçador da norma social, de fato, é a antecipação do sentimento de vergonha que a violação da norma causaria" (Elster, 1993, p. 124). Creio que, pela colocação de Elster, parece claro que são nossas leis determinadas por nossa ética e não o contrario, e a ética pelos costumes (mores) e/ou caráter (ethos) ${ }^{1}$ da sociedade; entretanto, é importante mencionar que tal processo é circular.

Para a sociedade hodierna, a ética comparativa tem cada vez maior importância, não importa que dada a multiplicidade do homo sapiens uma homogeneização da dimensão ética do gênero humano seja impossível, o que importa é que na maioria das sociedades há valores que estão de acordo com os de outra. Claro está, uma unidade ética é impossível, mas uma unidade legal entre alguns países é provável em função dos blocos econômicos cada vez mais coesos.

O processo de globalização da economia em curso é com toda certeza um dos acontecimentos mais significativos dessa segunda metade de século e tem implicações para todos os indivíduos. Não menos interessante é o fato de os mercados financeiros embora tendo sido os primeiros a se integrarem a nível global constituam até o momento o principal fator de risco para o processo. $\mathrm{O}$ fato dos diversos mercados financeiros terem iniciado o processo de integração global não é surpreendente, dado o papel de transferencia de risco e alocação eficiente de recursos que estes mercados desempenham, não é apenas coerente a integração de tais mercados, mas uma condição sine qua non para desencadear e sustentar o processo de globalização/integração econômica como um todo. A revolução da informática, concomitante com a queda do sistema de Bretton Woods (1973), no último quartil desse século, veio corroborar um nível de integração inesperado e deu azo ao que ficou conhecido como capital errante; dinheiro especulativo (e extremamente volátil) que circula pelo mundo em busca das melhores oportunidades de ganho. $\mathrm{O}$ capital já não tem pátria. $\mathrm{O}$ risco de uma quebra do sistema financeiro global é uma realidade. A velocidade com que a informação circula através desses mercados é surpreendente e pode ser melhor expressa através de exemplos recentes como a crise desencadeada nos mercados asiáticos e, anteriormente, a crise mexicana (efeito tequila), que tiveram conseqüências sobre diversos países em uma velocidade sem precedentes.

\footnotetext{
${ }^{1}$ Os temos mores e ethos são tratados, para efeito desse artigo, como sinônimos.
} 
Seja a ética dos diversos agentes atuantes nos mercados financeiros, seja a legislação sobre eles incidente, parecem não ter acompanhado a velocidade da revolução tecnológica, mormente a da tecnologia da informação, ou não viveríamos um clima de permanente tensão nos mercados financeiros. O processo da modernidade parece ocorrer em duas frentes que se deslocam em velocidade distinta; seus elementos frios - ciência, tecnologia, empresamento econômico, crítica epistemológica aparentemente apresentam uma velocidade superior em seu desenvolvimento em relação aos chamados elementos quentes - cidadania universal, dessacralização da cultura, emergência das Ciências Sociais, consciência dos signos - (Santos, 1991). Esta diferença de velocidade poderia, ao menos em parte, explicar parcela do problema, nossa heterogeneidade intercultural e interpessoal contabilizaria, quem sabe, outra parcela significativa.

Nesta primeira parte, procurei chamar a atenção para três abordagens, duas delas bastante comuns, da ética. A ética aristotélica ou ética da virtude e a ética relativista ou pragmática; refiro-me aqui a abordagem do relativismo moral existencialista. Chamei essas duas primeiras abordagens pela ordem normativa e descritiva. Apresentei uma terceira abordagem, que chamarei aqui pluralismo moral, a qual fundamentei em Gellner, Santos e Berlin, onde admite-se a pluralidade de fins diferentes, mas todos moralmente legítimos, que podem ser buscados pelos Homens. O pluralismo moral, a que me refiro, pode ser entendido como uma variante da segunda abordagem. Apontei a ética comparativa como, na atualidade, a mais importante no sentido de contribuir para a integração internacional (em qualquer nível). Comentei o trinômio ética $X$ legislação $X$ liberdade, a integração dos mercados financeiros concomitante com a revolução da informática e o possível descompasso de velocidade entre os diversos elementos da modernidade como parcialmente responsável pelos recentes problemas no mercado financeiro global, ou seja capital errante e risco sistêmico.

\section{ÉTICA EM NEGÓCIOS}

Antes de tratar de ética em finanças, cabem algumas considerações a respeito de ética nos negócios em geral e uma definição do que seria essa ética. De acordo com Nash (1993), os executivos tem basicamente dois tipos de preocupação no que se refere a ética. A primeira diz respeito ao efeito de adotar-se padrões morais elevados sobre os resultados financeiros da corporação. Nesse contexto ser ético tem necessariamente um custo associado. A segunda preocupação está ligada ao temor de que a adoção de padrões não-éticos pelos empregados venha a se constituir em um passivo financeiro caso tais padrões cheguem a público.

A autora define a ética dos negócios como “ ... o estudo da forma pela qual normas morais pessoais se aplicam às atividades e aos objetivos da empresa comercial.” (Nash,1993, p.6). Não se trata, portanto, de um tipo especial de ética, mas sim da utilização das normas morais pessoais no contexto dos negócios acompanhado do estudo de como o ambiente empresarial afeta certos valores pessoais dos agentes envolvidos. (Nash, 1993).

Amoêdo (1997) chama a atenção para o fato de que os agentes tomadores de decisões devem ter uma visão contextualizada da realidade com que se deparam para só então determinar o curso de ação. A vida do executivo em uma organização é acompanhada de uma série de demandas e pressões que geram dilemas de difícil solução. Uma vez que a avaliação da linha de conduta passa tanto pelos fatores organizacionais quanto pelos pessoais, não é recomendável uma postura romântica por parte do executivo. 
Por outro lado, as empresas certamente não agem eticamente apenas para não sofrer penalidades legais, existe uma diferença profunda entre legalidade e moralidade. "As empresas agem eticamente (em conformidade com a moral socialmente predominante), porque as relações travadas entre empresas $e$ contrapartes são relações de força, relações de poder". (Srour, 1994). Agir eticamente deixa de ser uma escolha e passa então a ser imperativo estratégico para a sobrevivência. (Srour, 1994).

As áreas mais importantes da ética empresarial no que tange a tomada de decisão gerencial dizem respeito ao cumprimento ou não da legislação, a primazia do interesse próprio sobre os interesses da companhia e outras partes interessadas e, assuntos que transcendem a esfera legal (Nash, 1993).

Fica claro que quando discutimos ética nos negócios estamos tratando justamente de escolhas quanto aos possíveis cursos de ação que podem ser tomados no âmbito organizacional e suas implicações de cunho moral.

\section{ÉTICA EM FINANÇAS}

As questões éticas permeiam todas as atividades humanas, mesmo porque os indivíduos sempre tem uma dimensão moral. A área financeira é reconhecidamente um território de mentes quantitativas, o tipo de ambiente onde a melhor expressão da ars gratia artis é um polpudo saldo bancário. Tenho certeza de que muitos dirão que não é bem assim, mas um financista que não ganha dinheiro, convenhamos, não é um bom financista e pergunto-me se alguém entregaria seus ativos para tal financista administrar. Vivemos em uma sociedade capitalista e consumista, nada mais a dizer; com raras e, porque não dizer, belas, necessárias e comoventes exceções, como Betinho e Madre Tereza, sabemos que a maioria absoluta de nós tem ideais de vida bastante distintos dos desses dois, que infelizmente já nos deixaram, não fosse assim o mundo já seria o paraíso terrestre e não um vale de lágrimas.

As pesquisas cientificas de caráter ético em finanças não são exatamente comuns, a preocupação tem se concentrado bastante sobre a regulamentação do mercado de modo a the garantir um mínimo de credibilidade bem como em estabelecer limites de exposição para os diversos agentes em função do risco sistêmico. Existe também um crescente interesse em avaliar o desempenho dos fundos de investimento com preocupações humanitárias ou fundos éticos em contraste com outros fundos e com índices de mercado (Dow Jones, FGV100, IBOVESPA, etc.) e em saber se atitudes éticas e/ou socialmente responsáveis levadas a cabo pelas empresas são legitimadas dentro do conceito de maximização da riqueza dos acionistas; bem como há uma grande preocupação em suavizar as arestas nos conflitos de agência entre corretores, investidores e firmas corretoras. E, finalmente, as universidades e empresas de todos os setores da economia tem apresentado crescente interesse pelo tema.

Caccese (1997), indica algumas possíveis razões para o crescente interesse por ética tanto em finanças como em outras empresas voltadas para o lucro:

$\rightarrow$ Pressão dos consumidores;

$\Rightarrow$ Melhorar a produtividade e o serviço aos clientes;

$\rightarrow$ Competitividade (ser ético é uma estratégia de marketing); 
$\rightarrow$ Mudanças nos valores da sociedade (pessoas primeiro, lucro depois); e

$\rightarrow$ Temor de dano monetário e na reputação por procedimento não ético.

Não há estudos conclusivos quanto ao efeito dos valores éticos sobre o valor de mercado de uma empresa.

Conflitos de Agência

Em um artigo de 1995, Spiro e Michael, apontam para uma onda de criticas às práticas que vem sendo adotadas a anos pelas corretoras de valores nos Estados Unidos. Tais criticas acusam as firmas corretoras e seus corretores de sistematicamente colocar os investidores em desvantagem. Políticas de remuneração baseadas quase que totalmente em comissões, concomitante com incentivos, como relógios, viagens de férias totalmente pagas e tratamento diferenciado aos corretores que geram maiores volumes de transações, concedidos pela venda de produtos que resultem em alto lucro para a firma, geram uma pressão que conduz os corretores a buscarem seus próprios interesses e os da corretora em detrimento dos de seus clientes. As firmas, segundo os autores, recomendam que seus corretores vendam os fundos de investimento da própria corretora, visando beneficiar-se das taxas de administração, entretanto, estes fundos muitas vezes apresentam retornos medíocres. Os corretores, nesse contexto, agem como meros vendedores.

Caccese (1997), chama a atenção para a existência de profissionais de origem diversa e nenhum treinamento formal em investimentos atuando na área de finanças. Posto que a profissão não é regulamentada e não exige formação acadêmica especifica para seu exercício, as pessoas que a praticam não apresentam valores éticos uniformes. Caccese defende que, além do código de ética para a profissão, três medidas devem ser tomadas para garantir que a prática siga o mais alto padrão ético:

$\rightarrow$ Criar grandes barreiras de entrada;

$\rightarrow$ Promover um programa de educação continuada para os profissionais, e;

$\Rightarrow$ Possuir um processo de fiscalização e julgamento claros, que puna os transgressores.

Cedo ou tarde todos falham em agir eticamente. Badaracco e Webb (apud Caccese, 1997), em estudo conduzido em 1995, constataram que na maioria das empresas "agir eticamente" significa trabalhar bem e ser leal ao chefe e a empresa e que, uma vez que não agissem fora da lei, os empregados não eram incentivados a “investir" em ética.

Para mitigar os conflitos de agencia entre os corretores e seus clientes tem sido defendido a adoção de códigos de ética pelas corretoras, legislação reguladora sobre o assunto e transparência nas relações acima de tudo (Caccese,1997). Shefrin e Statman (1993), chamam a atenção para o fato de que regras não paternalistas proibiriam os corretores de travestir os papéis que recomendam a seus clientes, obrigando-os a prestar as informações corretas, se solicitadas, quando estas fossem disponíveis. Entretanto, não demandariam que estes mesmos corretores solicitassem informações sobre a situação financeira e os objetivos de seus clientes ou mesmo se abstessem de recomendar papéis que julgassem pouco recomendados. Em um modelo não paternalista os clientes retém o direito e a responsabilidade de decidir e determinar o que lhes for apropriado. Os autores colocam que o sistema legal em vigor, a respeito desse assunto, parece ser bastante paternalista, isto indica que o legislador, nesse caso, acredita que erros cognitivos e falta de autocontrole por parte dos investidores são comuns e devem ser remediados; mesmo ao custo de menor eficiência e direito de liberdade contra coerção. 


\section{A ÉTICA DA VIRTUDE EM FINANÇAS - DOIS ARTIGOS DE DOBSON}

Dobson, buscando demonstrar o papel da ética em finanças, diz que "A teoria econômico-financeira promulgou seu tipo particular de hedonismo. Assumindo que a única motivação razoável para o comportamento humano é a maximização da riqueza pessoal, sancionou e promoveu tal comportamento entre a comunidade financeira." (Dobson, 1993, p. 57). Sob esse prisma, diz que a ética em finanças tende a ser vista apenas dentro do rígido conceito da teoria financeira, e que, por isso, assume o papel ambíguo e subserviente de legitimar alguns objetivos materialistas. Afirma que a atual concepção de ética, como uma restrição ao comportamento, é ilógica, pois sanciona comportamentos não éticos se estes levarem a ganhos financeiros; nessa mesma linha de raciocínio, crítica os que afirmam que o comportamento ético é uma restrição necessária e desejável por manter o nível de confiança no mercado.

Partindo das observações acima, Dobson coloca que "por definição, a ética preocupa-se com as motivações para o comportamento humano. Não é possível determinar se um indivíduo é ético pela observação de suas ações, isto só pode ser determinado pela observação de suas motivações para aquelas ações." (Dobson, 1993, p. 57). A partir disso, Dobson oferece uma abordagem baseada na ética da virtude; chama essas virtudes desejáveis de "bens internos", os quais seriam o objetivo último de todo o esforço humano. É uma ética baseada no agente e que depende do bom julgamento moral do mesmo; deste modo a acumulação de riqueza pode então ser vista em um contexto mais balanceado, como uma função necessária dos mercados financeiros, mas não como o objetivo último de todo o esforço humano nesta ou em qualquer esfera. Os primeiros passos para essa mudança de paradigma seriam a teoria econômico-financeira reconhecer seu papel normativo e assumir explicitamente que motivos comportamentais outros, que não a maximização da riqueza, são ao mesmo tempo desejáveis e realistas.

Em artigo publicado em 1997, Dobson indica como atributos para a busca da excelência: virtudes, comunidade, bom julgamento moral e exemplos. A seguir, sua visão de cada um deles.

\section{O Papel das Virtudes}

"A virtude é uma qualidade humana adquirida, cuja posse e exercício tende a permitir-nos alcançar aqueles bens que são internos” (Alasdair MacIntyre, 1984, apud Dobson, 1997, p. 16).

\section{O Papel da Comunidade}

$\mathrm{Na}$ ética da virtude, a racionalidade é uma racionalidade compartilhada, com uma concepção compartilhada daquilo que é realmente (essencialmente) desejável em todo esforço humano. Essa concepção deve ser legitimada e corroborada pelas organizações e instituições que controlam e dirigem a atividade humana.

\section{O Papel do Julgamento Moral}

A ética da virtude rejeita a abordagem calcada em regras para a educação moral. A ética da virtude é um processo em busca da excelência, que admite a manutenção ou quebra de regras desde que conduzam a excelência. Neste contexto, seguir o aparato legal não deve ser visto como uma atitude necessariamente ética, mas sim como o fundamento a partir do qual o ideal profissional naquela atividade deve ser perseguido. 


\section{O Papel dos Exemplos Morais}

O aprendizado moral não consiste primariamente no aprendizado de regras, mas na aquisição de exemplos pertinentes. Um modelo adequado pode ser didaticamente mais efetivo do que um conjunto de máximas comportamentais. Os conflitos e ambigüidades estão no cerne da abordagem baseada no agente. Esta é a razão pela qual a habilidade de fazer bons julgamentos morais é tão crítica e o conhecimento através da observação de exemplos, dentro de um sistema organizacional que alimenta tal conhecimento, é crucial.

\section{Ética da Virtude e o Profissional de Finanças}

Segundo o autor, a ética da virtude fornece o que nos é fundamentalmente mais necessário: um objetivo ou ideal em nossa vida profissional. Afirma que para buscar esse ideal há dois princípios fundamentais:

(1) Ver a profissão como uma prática;

(2) Nessa prática buscar o "bem interno" acima de todo o resto.

Os atributos da profissão para que esta seja uma prática :

(1) Deve estabelecer seus próprios padrões de excelência e ser em parte definida por eles;

(2) Deve ser dirigida ao objetivo (teleológica);

(3) Deve ser orgânica (acompanhar a evolução).

Os atributos dos "bens internos" dentro dessa prática:

(1) Serem únicos àquela atividade;

(2) Serem ilimitados;

(3) Serem intangíveis; não podendo ser simplesmente definidos, quantificados ou matematicamente enumerados.

Segundo Dobson, deve-se ensinar aos profissionais a superioridade inerente dos "bens internos" em oposição aos "bens externos"; e fazê-los ver que não são seres atomísticos, mas parte de uma prática profissional. Os credos existem nas corporações para disseminar tal ética pessoal. Ao invés de apresentar a ética como uma restrição ao comportamento, um código corporativo baseado na ética da virtude enfatiza o papel da excelência moral como um objetivo. Em suma, tal ética coloca a virtude acima do ganho material. Por serem os códigos de ética corporativos insuficientes para garantir uma conduta ética; os programas de treinamento são essenciais.

Vale acrescentar que a ótica de Dobson (1993 e 1997), embora guarde pontos de intersecção com a abordagem de Caccese (1997), parte de uma lógica oposta, haja vista que a visão de Dobson está embasada no agente e seu "bom julgamento moral", ao passo que Caccese parte de uma abordagem baseada na ação e define a ética pelas ações do agente e não por suas intenções ou motivações para aquelas ações. Na seção 5 abordo o assunto considerando a ética baseada na conseqüência da ação ou seus resultados, ótica que me parece mais apropriada. 


\section{O DILEMA JUSTIÇA X EFICIÊNCIA}

Nos mercados financeiros a eficiência é composta de dois fatores: eficiência de Pareto e eficiência informacional. A eficiência de Pareto existe quando não há opção de alocação de recursos e tecnologia que possa melhorar a situação de um indivíduo sem que haja prejuízo de outro (Ruffin e Gregory, 1983). Em outras palavras há alocação eficiente de recursos e maximização da produção na presença desse tipo de eficiência. Não há garantias, entretanto, de que os agentes não cometam erros. Eficiência informacional, diz respeito a disponibilidade das mesmas informações a todos os participantes do mercado e ao mesmo tempo (simetria informacional), isto garante que os preços reflitam as informações disponíveis e consideradas relevantes, isto é os preços são eficientes quando há simetria informacional. Novamente não há garantias de que os preços assim formados serão seguidos - em 13 de outubro de 1989 o índice Dow Jones Industrial Average caiu 190 pontos sem nenhuma noticia negativa associada.

Shefrin e Statman, dizem que as leis sobre o assunto são o resultado de um cabo de força entre eficiência e justiça em que a força relativa muda continuamente de um lado para outro. A definição do que seja justo em termos de mercados financeiros é tema controverso. Uma definição possível seria a de que todos os participantes tivessem igual acesso a informação relevante para precificar os ativos, todavia, essa transparência forçada, não poderia dar azo a regulamentações sobre margem, emissão e venda de títulos, promotores e vendedores de títulos e responsabilidade dos corretores para com seus clientes. Para abarcar esses aspectos é necessária uma definição mais abrangente do que seja justo no mercado financeiro (Shefrin e Statman, 1993).

Segundo Shefrin e Statman, justiça pode ser vista como uma série de requisitos, e identificam sete aspectos que deveriam ser contemplados para que um mercado fosse justo:

$\rightarrow$ Liberdade contra coerção $\vec{\uparrow}$ Garantia de poder decidir livremente se deseja entrar em uma transação;

$\rightarrow$ Liberdade contra falsa representação $\vec{\jmath}$ Garantia de que as informações são completas e verdadeiras;

$\rightarrow$ Informação igual $\oplus^{\circ}$ Garantia de acesso a informação para todos (simetria);

$\rightarrow$ Poder de processamento igual $\widehat{\phi}^{\prime}$ Garantia de um patamar mínimo de habilidade para processar as informações disponíveis. Essa classe de justiça reconhece que algumas pessoas cometem erros cognitivos, e assume a forma de abertura compulsória de informação ou proibição de que certas transações sejam levadas a efeito diretamente. No Brasil o código de defesa do consumidor ao obrigar a informação sobre taxas de juros nos financiamentos e clausulas de arrependimento, provavelmente segue essa linha de raciocínio;

$\rightarrow$ Liberdade contra impulsos $\vec{\gamma}$ Garantia de que as pessoas sejam protegidas contra falta de autocontrole. Este item e o anterior são normalmente concedidos na forma de paternalismo.

$\Rightarrow$ Preços eficientes $\vec{\omega}$ Garantia de que as pessoas tenham os preços que percebem como eficientes, neste contexto, intervenções de especialistas para corrigir desbalanceamentos que possam distorcer os preços é permitida. Há, naturalmente, uma diferença fundamental entre preços informacionalmente eficientes e preços percebidos como eficientes, é suficiente dizer que na presença de simetria informacional, ceteris paribus, os preços deveriam poder flutuar livremente para que fossem eficientes; 
$\rightarrow$ Igual poder de barganha $\overleftrightarrow{\varphi^{\prime}}$ Garantia de igual poder nas transações, um exemplo seriam os tetos máximos para taxas de juros nos financiamentos.

É fácil observar que diversos aspectos do que seria justo em um mercado financeiro entram em choque direto com o que considera-se eficiência de mercado, o "debate sobre eficiência e justiça e os papéis das forças de mercado e os agentes reguladores revela, certamente, um continuo esforço da sociedade, através de seu processo legislativo, para encontrar o equilibrio correto entre os elementos" (Shefrin e Statman, 1993, p. 28).

Naturalmente, a legislação evolui de acordo com a evolução da sociedade, os legisladores operam como analistas de investimento, algumas combinações de eficiência e justiça são melhores que outras. A fronteira eficiente do binômio eficiência/justiça é composta por combinações que não podem ser superadas, escolhas ao longo da fronteira elevam um dos elementos e reduzem o outro. A tomada de decisão, entretanto, é complexa uma vez que seus elementos são multidimensionais. Aos defensores da eficiência total, vale transcrever Isaiah Berlin "Tanto a liberdade quanto a igualdade estão entre os objetivos básicos procurados pelos seres humanos durante muitos séculos; mas a liberdade total para os lobos é a morte para os cordeiros; a liberdade total dos poderosos, dos talentosos, não é compatível com o direito de uma existência decente para os fracos e os menos talentosos.” (Berlin, 1991, p. 22).

\section{FUNDOS ÉTICOS E SEU DESEMPENHO}

Tem havido um significativo aumento no número de fundos éticos em diversos países nos últimos dez anos. Um fundo ético é definido como aquele que tem um critério de investimento "positivo" ou "negativo". Os fundos com "critério negativo" devem apresentar uma política de não investir em certos setores, como por exemplo, álcool, tabaco, jogo, armamento, pornografia, etc. ou em certos países, como por exemplo, aqueles com regimes opressivos. Os fundos com "critério positivo" devem apresentar uma política de investimento em empresas que sejam ecologicamente responsáveis. Alguns fundos tem objetivos que combinam critérios positivos e negativos. A maioria dos estudos tem dado atenção as políticas de investimento desses fundos, isto é, se as empresas em que tais fundos vem investindo apresentam, de fato, um padrão ético em suas operações (Mallin et al., 1995).

A maioria dos estudos parece indicar que os fundos de investimento em geral não superam o mercado, os estudos nesse sentido com respeito aos fundos éticos não são conclusivos, pois é difícil dissociar os aspectos éticos do efeito tamanho. Em estudo conduzido no Reino Unido em 1995, Mallin et. al. procuraram superar essa dificuldade utilizando uma amostra agrupada de fundos éticos e fundos sem esse tipo de restrição. Para isso utilizaram uma amostra emparelhada de 29 fundos, procurando ajustar os pares no que se refere ao início da operação e ao tamanho dos mesmos. Naquele estudo utilizaram como proxy para o retorno mensal do mercado o Financial Times All Share Actuaries Index e o retorno mensal das T-Bills como proxy para a taxa livre de risco. Testaram então duas hipóteses nulas:

$\rightarrow$ (I) “Os fundos de investimento ético não superam o mercado."

(II) "A performance dos fundos de investimento ético não é diferente daquela dos fundos de investimento não ético." (Mallin, et al. ,1995, p. 487)

Utilizaram três medidas consagradas de performance baseadas no CAPM ex-post, os índices de Sharpe, de Treynor e de Jansen, conforme o quadro 1 abaixo. Os resultados obtidos por Mallin et al. indicam 
que os fundos éticos apresentam performance levemente superior aos fundos não éticos para as três medidas; o índice de Jensen foi o que apresentou resultado mais favorável aos fundos éticos.

\section{Quadro 1. Metodologias Baseadas no CAPM ex-post - Modelos de performance}

\begin{tabular}{|c|c|c|}
\hline $\begin{array}{l}\text { Sharpe } \text { मे } \\
S_{p}=\frac{r_{p}-r_{f}}{\sigma\left(r_{p}\right)}\end{array}$ & Onde : & $\begin{array}{l}r_{p}=\text { Retorno real médio } \\
r_{f}=\text { Taxa livre de risco média } \\
\sigma\left(r_{p}\right)=\text { Desvio padrão dos retornos }\end{array}$ \\
\hline $\begin{array}{l}\text { Treynor 证 } \\
T_{p}=\frac{r_{p}-r_{f}}{\beta_{p}}\end{array}$ & Onde : & $\beta_{p}=$ Risco de mercado da carteira (risco sistemático) \\
\hline $\begin{array}{l}\text { Jensen मे } \\
J_{p}=r_{p}-r_{f}=\alpha_{p}+\beta_{p} X+\varepsilon_{p}\end{array}$ & Onde: & $\begin{array}{l}\alpha_{p}=\text { Capacidade de seleção } \\
\beta_{p}=\text { Risco sistemático do portifólio } \\
X=\left(r_{m}-r_{f}\right) \\
r_{m}=\text { Retorno do mercado }\end{array}$ \\
\hline
\end{tabular}

A performance superior dos fundos éticos, entretanto, é pequena e os autores chamam a atenção para a possibilidade do fenômeno ser temporário e devido ao aumento de interesse e consciência em relação a investimento ético; o que conduziria a um aumento na demanda por produtos de investimento adequado, estabelecendo um prêmio nos retornos realizados. Naturalmente, o fenômeno pode continuar na medida em que os investimentos éticos ganhem maior aceitação. Os resultados obtidos entretanto não podem ser considerados conclusivos, mesmo porque, em se considerando um mercado perfeitamente eficiente, tentativas de se obter retornos anormais, via seleção de um portfólio de ativos, não deveriam, em tese, proporcionar performances superiores a um portfólio de mercado.

\section{ÉTICA NOS NEGÓCIOS E MAXIMIZAÇÃO DA RIQUEZA DOS ACIONISTAS}

O problema, quando admitimos a maximização da riqueza dos acionistas como objetivo básico da administração financeira, consiste em saber se e como o mercado incorpora preocupações éticas e responsabilidade social na formação dos preços. Isto leva a questão insolúvel de definir o que afinal constitui um comportamento adequado, isto é, que tipo de comportamento o mercado deveria recompensar. Além disso, se introduzirmos os custos de agencia como uma variável adicional, cabe perguntar também, o que constitui comportamento ético por parte da administração do negócio, principalmente no tangente aos interesses dos acionistas.

Em artigo de 1994, Poitras aponta para uma série de dificuldades que se apresentam ao tentar-se avaliar se um comportamento ético interfere nos preços. Preocupações éticas só seriam justificáveis e incluídas no fluxo de caixa de projetos, se apresentassem reflexos sobre o preço da ação no mercado. Considerando a hipótese de que os mercados fossem eficientes, ou seja, refletissem de imediato as informações sobre as decisões dos administradores, uma informação a respeito de atitudes éticas e/ou socialmente responsáveis deveria produzir um reflexo imediato nos preços, entretanto o comportamento do mercado financeiro no curto prazo é histérico e o real efeito de uma notícia de cunho ético são difíceis de provar 
Se o mercado discrimina entre empresas por razões éticas cabe perguntar como seria possível verificar se os preços observados refletem considerações éticas válidas da parte dos administradores. Outra dificuldade, diz respeito a possibilidade de generalizações a partir dos resultados, uma vez que as culturas dos diversos países são diferentes, é duvidoso que estudos desse tipo levassem a generalizações úteis.

Poitras (1994), afirma que mesmo considerando uma visão puramente legalista, isto é, ser ético é agir de acordo com as leis, é difícil sustentar que a maximização da riqueza dos acionistas seja capaz de deter o comportamento ilegal, embora haja razoáveis evidências de que o mercado desconta pesadamente aquelas ações cujas empresas se engajaram em atividades ilegais. Entre as críticas à abordagem legalista esta o fato de que o sistema legal não é imune a manipulações de interesses econômicos, o que poderia permitir que os administradores entrassem em atividades não éticas. Naturalmente, é possível argumentar que algumas atividades legais não são necessariamente éticas e vice-versa. Se a maximização da riqueza dos acionistas é o objetivo precípuo dos gestores empresariais, parece haver pouco incentivo em direção a ações éticas e socialmente responsáveis; a menos que tais ações coincidam com a maximização da riqueza dos acionistas.

Graham \& Krueger (1996), entretanto, apresentam um estudo que compara a opinião de estudantes de finanças americanos e executivos financeiros do primeiro escalão ( $C F O$ 's) a respeito de uma série de atributos indicados pelos últimos como importantes na educação de futuros executivos. A diferença de opinião entre os grupos foi significante ao nível de 0,01. A quase totalidade dos executivos indicou a ética como elemento mais importante para um recém graduado, indicando a mesma como "essencial". Entre os estudantes, dos nove atributos pesquisados, a ética foi classifica em último ou penúltimo lugar, conforme a segmentação da amostra. A evidente preocupação dos executivos com relação a ética parece indicar que não é apenas a maximização da riqueza dos acionistas que conta. Por outro lado seria interessante verificar se o que os executivos consideram ético é comum a todos eles.

\section{CONSIDERAÇÕES FINAIS}

Penso ser relevante comentar alguns aspectos do que foi explanado na parte anterior. Existe um grande número de pesquisas em finanças corporativas voltadas para o problema da agência, isto é, o conflito de interesses entre gestores e acionistas. O problema de fato existe e a teoria financeira sugere uma série de medidas com o objetivo de mitigar os conflitos, entre eles a manutenção de um certo nível de endividamento (Copeland e Weston, 1988). Exceto pelos artigos já discutidos não encontrou-se literatura que tratasse especificamente do conflito entre investidores e corretores. O que fica óbvio é que o problema existe também nessa esfera, e as soluções, muito provavelmente, devem vir via legislação reguladora. Outro aspecto interessante, é que, de fato, é possível justificar as atitudes de ambas as partes, é possível compreendê-las e, sem sombra de dúvidas, o que é ético para um é errado para o outro.

Quando uma das partes detém maior poder em relação a outra, creio que, dado o nosso estágio de evolução, o único caminho é uma abordagem legalista e, nesse caso, com uma legislação paternalista. Este tipo de legislação não altera a relação do investidor especializado com sua firma corretora, uma vez que este tipo de investidor costuma atuar de modo bastante consciente; em contrapartida protege o pequeno investidor, normalmente com poucos recursos e conhecimentos de mercado, ao mesmo tempo que promove maior confiança no mercado como um todo. $\mathrm{Na}$ seção 4.3, parece ficar claro que uma 
certa quantidade de legislação é mesmo necessária para manutenção do que podemos chamar equilíbrio dinâmico, já que a legislação deve acompanhar a evolução da sociedade.

A ética da virtude em finanças me parece ótima em teoria, mas estou convicto que de que é um verdadeiro desastre na prática em finanças ou qualquer outra área. Por outro lado, não creio ser possível uma abordagem da ética baseada na intenção do agente. A menos que nos tornemos telepatas; como poderíamos determinar a motivação intrínseca para a ação dos indivíduos e mais, como, mesmo sabendo das intenções do agente, poderíamos evitar a atitude pouco ética; e o que dizer daquelas ações que aparentemente vão em benefício de todos e acabam por produzir resultados desastrosos, o agente era bem intencionado não há dúvida, mas o que conta é a intenção ou os efeitos da ação?

A ética da virtude apresenta outros problemas, como a tentativa evidente de reduzir a multiplicidade a uniformidade. A observação de Huxley parece adequada; "Durante sua evolução, a natureza não se furtou a desgraças sem fim para que cada individuo fosse diferente dos outros individuos. Reproduzimos a nossa espécie estabelecendo contato entre os genes do pai e os genes da mãe. Esses fatores hereditários podem ser dispostos num número quase infinito. Física e mentalmente, cada um de nós é exclusivo. Qualquer cultura que, no interesse da eficácia, ou em nome de qualquer dogma político ou religioso, procura padronizar o indivíduo humano, comete um ultraje contra a natureza biológica do Homem." (Huxley, 1959, p. 36 e 37). Além disso, a ética da virtude pode enveredar para uma espécie de tirania, justificável em nome das virtudes que o reformador julga adequadas e corretas. (Berlin, 1981).

Compartilho a opinião de que não existe um ideal único, o que existe é uma multiplicidade de ideais. Creio que impor um sistema de valores absolutos à área de finanças é criar ineficiências. Esta é o tipo de área de atuação em que a diversidade de formação dos participantes é fator não apenas enriquecedor, mas a meu ver, necessário. Não compartilho da visão de Caccese, de que se devam criar barreiras de entrada, creio que devemos buscar outro tipo de solução.

A ética deve ser abordada sob o prisma do resultado que as ações dos diversos agentes produzem e suas interconexões posteriores. Nessa ótica, não é a ação de per si que define o caráter ético ou não, mas sim os resultados práticos produzidos por aquele ato. Assim, a ética baseada na ação a que Caccese (1997) se refere, adquire uma dimensão mais complexa e abrangente, bem como fica exposto o calcanhar de Aquiles da ética aristotélica, o "bom julgamento moral do agente", uma vez que tal capacidade de julgamento e motivação serão tão heterogêneas entre agentes em diferentes posições que a possibilidade de dois indivíduos julgarem uma situação exatamente da mesma maneira é tão improvável quanto a existência de dois flocos de neve exatamente iguais. Abordar a questão pelo resultado limita algumas falácias da ética aristotélica, pois a primeira não se baseia nas motivações do agente; entretanto apresenta pelo menos um problema. Não é a lógica da abordagem pelo resultado que cria o problema, mas sim a existência de sérias limitações quanto a sua aplicabilidade em função do número de interconexões que uma ação aparentemente isolada pode produzir, isto torna a análise limitada e, por isso, falível para a maioria dos casos; data venia esta ainda me parece uma forma mais coerente de abordar as questões éticas em comparação com as duas anteriores.

\section{CONCLUSÃO}

Embora seja impossível, no momento, afirmar que ações éticas tem valor financeiro, isto é, impacto sobre a riqueza dos acionistas, o crescente interesse pelo assunto em todas as áreas parece sinalizar com um período de revisão de nossos valores e de nossas opiniões sobre o assunto. Quem sabe o próximo 
milênio será marcado pelo desenvolvimento acelerado dos elementos quentes da modernidade, quem sabe novas técnicas de análise permitam determinar com precisão o valor, se é que existe, das ações éticas no meio empresarial. Seguem algumas sugestões para pesquisas futuras.

Seria interessante uma análise da capacidade de market timing dos administradores dos fundos éticos e não éticos. $\mathrm{O}$ market timing consiste em prever, entre duas ou mais classes de ativos, qual delas deverá obter o maior retorno, o administrador sempre deverá investir no portfólio que acredita será mais rentável, em outras palavras é a habilidade de prever os movimentos do mercado.

A habilidade de market timing poderia, talvez, explicar o desempenho ligeiramente superior dos fundos éticos da amostra. Outro aspecto que faria jus a atenção, diz respeito a habilidade do fundo em selecionar títulos subavaliados (security selection), ver quadro 2 a seguir.

Quadro 2. Performance em Termos de Market Timing e Security Selection

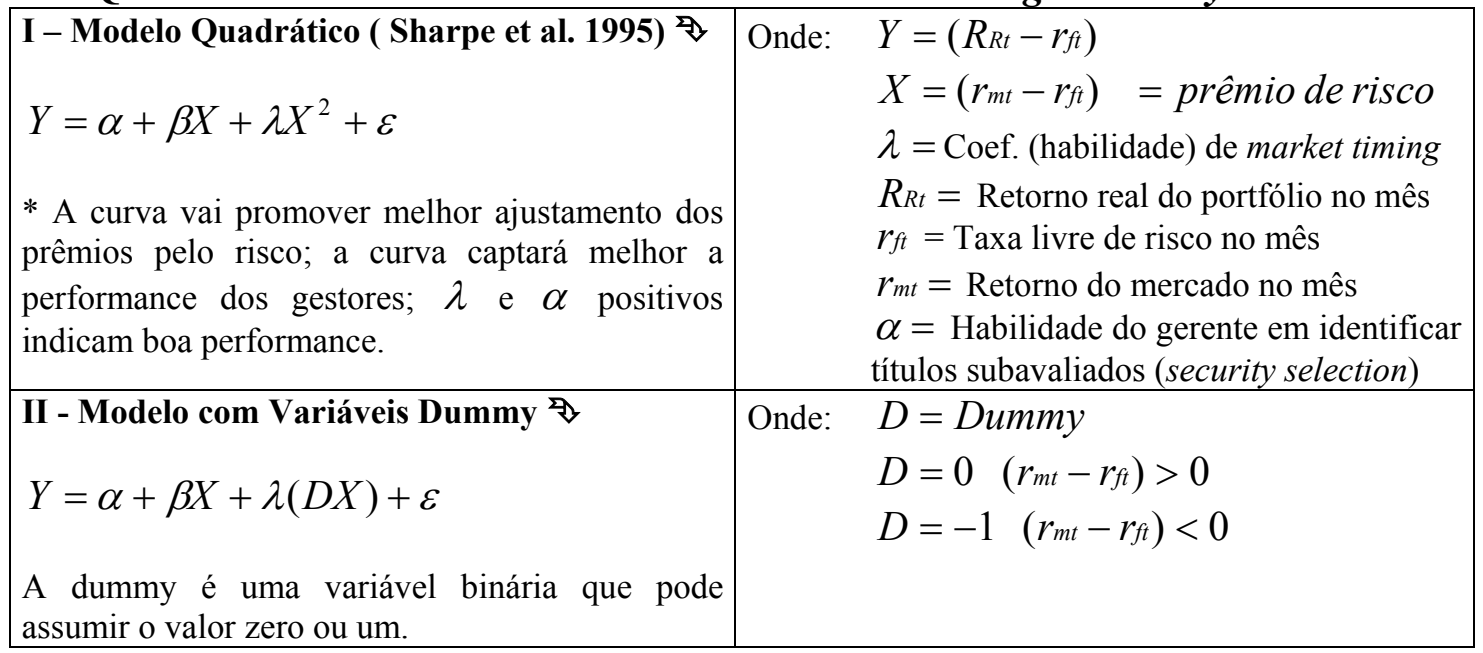

Ainda em relação aos fundos de investimento ético, seria interessante verificar o perfil dos clientes que optam por esse tipo de fundo. Através de um melhor conhecimento do público consumidor desses produtos nos diversos países, talvez fosse possível inferir se o crescente interesse nesses investimentos é uma febre passageira ou uma tendência auto-reforçadora. Caso não fosse um modismo, teríamos uma indicação forte de que comportamento ético por parte das empresas tem valor; o aspecto quantitativo, entretanto permaneceria um mistério.

Verificar a presença de conflitos de agencia entre investidores e gestores, bem como o efeito da legislação reguladora do setor de fundos sobre a percepção de risco dos investidores, apenas a título ilustrativo, de janeiro a agosto de 1998 cerca de 20 novas normas foram baixadas pelo BACEN, CVM e via medidas provisórias (Gazeta Mercantil, 31/08/1998).

Cabe observar que o conceito de marketing é aplicável à área financeira, bem como aos negócios em geral, a abordagem deve por isso mesmo estar centrada nos clientes atuais e potenciais. Se por um lado, isso não garante que os resultados de certos atos contenham vieses pouco éticos, pelo menos protege as relações fornecedor/cliente e contribui para mitigar os conflitos de agência. 
Minhas observações são fruto de minha formação, experiência, dos valores que internalizei ao longo de minha vida e da interação com outros indivíduos, posso estar errado e gostaria de estar, mas o que tenho observado é que existe uma distância abissal entre o que pensamos, o que expressamos verbalmente, o que nos dispomos a documentar, o modo como efetivamente agimos e os resultados que acabamos produzindo.

\section{Artigo recebido em 15.07.1999. Aprovado em 20.06.2001}

\section{REFERÊNCIAS BIBLIOGRÁFICAS}

AMOÊDO, Sebastião. Ética do trabalho. Rio de Janeiro: Qualitymark, 1997.

SANTOS, Francisco de Araújo. Ethics and irony: the manager's predicament. Apostila de Ética e Dinâmica da Sociedade, Porto Alegre, MS/PPGA, 1997.

. As dimensões da ética e o mundo organizacional. Apostila de Ética e Dinâmica da Sociedade, Porto Alegre, PPGA/UFRGS, 1991.

. O liberalismo. Porto Alegre: EdUFRGS, 1991.

. A emergência da modernidade - atitudes, tipos e modelos. Petrópolis: Vozes, 1990.

BERLIN, Isaiah. Limites da utopia - capitulos da história das idéias. São Paulo: Cia. das Letras, 1991. Cap. 1. . Quatro ensaios sobre a liberdade. Brasília: EdUnB, 1981.

CACCESE, Michael S. Ethics and the financial analyst. Financial Analysts Journal, v.53, n.1, p.9-14, Jan./Feb., 1997.

Compton's interactive encyclopedia. Compton's New Media, 1996.

COPELAND, Thomas. E. E., WESTON, J. Fred. Financial theory and corporate policy. 3 ed. Reading: Addison-Wesley, 1988.

DOBSON, John. Ethics in finance II. Financial Analysts Journal, v.53, n.1, p.15-25, Jan./Feb., 1997. . The role of ethics in finance. Financial Analysts Journal, p.57-61, Nov./Dec., 1993.

ELSTER, Jon. Egonomics: the economics of personal conflict. In: The Great Ideas Today (1993), Chicago: Encyclopaedia Britannica, p.87-135, 1993.

GELLNER, Ernest. Antropologia e política - revoluções no bosque sagrado. Rio de Janeiro: Zahar, 1995. Cap. 1.

GRAHAM, Lise, KRUEGER, Thomas M. What does a graduate need?: conflicts in CFO and student opinions. Financial Practice and Education, p.60-67, Fall/Winter, 1996. 
HUXLEY, Aldous. Regresso ao admirável mundo novo. São Paulo: Circulo do Livro, 1985.

Legislação garante mais segurança para aplicadores. Gazeta Mercantil, São Paulo, 31 ago. 1998, caderno relatório: dossiê fundos de investimento, p.10.

MALLIN, C. A., SAADOUNI, B., BRISTON R. J. The financial performance of ethical investiment funds. Journal of Business Finance \& Accounting, v.22, n.4, p.483-496, Jun., 1995.

MAQUIAVEL, Nicolau. O príncipe e dez cartas. 3 ed. Brasília: EdUnB, 1996.

NASH, Laura. L. Ética nas empresas: boas intenções a parte. São Paulo: Makron Books, 1993. Cap. 1.

POITRAS, Geoffrey. Shareholder wealth maximization, business ethics and social responsability. Journal of Business Ethics, v.13, n.2, p.125-134, Feb, 1994.

RUFFIN, Roy J., GREGORY, Paul R. Principles of economics. Glenview: Scott, Foresman and Co., 1983. Cap. 22 e 29.

SHARPE, William F., ALEXANDER, Gordon J., BAILEY, Jeffery. V. Investments. 5 ed. New Jersey: Prentice Hall, 1995.

SHEFRIN, Hersh, STATMAN, Meir. Ethics, fairness and efficiency in financial markets. Financial Analysts Journal, p.21-29, Nov./Dec., 1993.

SPIRO, Leah. Nathans, SCHROEDER, Michael. Can you trust your broker. Business Week, p.70-76, Feb., 20, 1995.

SROUR, Robert Henry. Ética empresarial sem moralismo. Revista de Administração, São Paulo; v.29, n.3, p.3-22, jul./set., 1994.

THORLEY, Lois. How green were my assets. Resident Abroad, p. 24-26, Jun., 1994. 